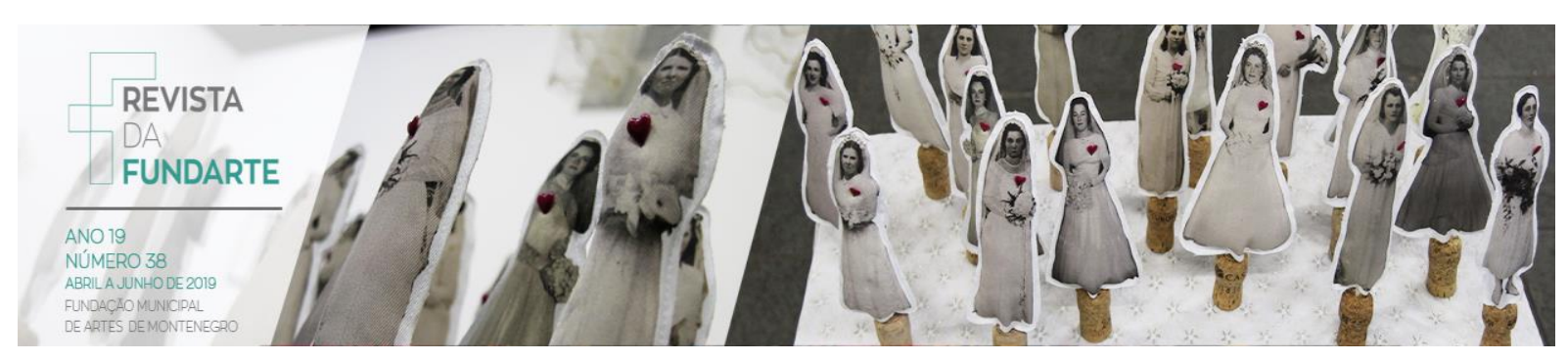

\title{
CORPOS CONSTRANGIDOS EM POTÊNCIA DE SENTIDOS: RASTROS CRIATIVOS DO ESPETÁCULO CACOS PARA UM VITRAL - GRUPO OITÃO CÊNICO - CARIRI/CE
}

Mauro Cesar Alves ${ }^{1}$

\begin{abstract}
Resumo: Esta escrita trata-se da extensão criativa do Oitão Cênico, grupo fundado em fevereiro de 2009 na região do Cariri cearense e, desde sua gênese, desenvolve uma linha de pesquisa e criação em continuidade a partir do questionamento: é possível criarmos uma obra cênica em que a circulação afetiva entre $o(a)$ artista da cena e o público seja potencializada durante uma apresentação? O resultado dessa pesquisa foi o espetáculo Cacos para um vitral, encenação em aberto, construída de forma colaborativa, com a intenção de compartilhar com o público um espelhamento das contingentes sensibilidades de corpos em estado de constrangimentos pessoais e sociais. Os documentos de criação foram revisados pela Crítica de Processos de Cecília Salles.

Palavras-chave: Poética de Grupo, Pesquisa Continuada, Processo de Criação.
\end{abstract}

\section{CONSTRANGED BODIES IN POWER OF SENSES: CREATIVE TRACES OF THE SPECTACLE CACOS PARA UM VITRAL - GROUP OITÃO CÊNICO - CARIRI/CE}

Abstract: This writing is the creative extension of Oitão Cênico, a group founded in February 2009 in the region Cariri, of Ceará, and since its genesis, has developed a line of research and creation in continuity from the questioning: it is possible to create a work in which the affective circulation between the artist of the scene and the audience is enhanced during a presentation? The result of this research was the spectacle Cacos para un vitral, staged, open-ended, collaborative, with the intention of sharing with the public a mirroring of the contingent sensibilities of bodies in a state of personal and social constraints. The creation documents were reviewed by Cecília Salles' Critique of Processes.

Keywords: Group Poetics, Continuing Research, Creation Process.

\section{Introdução}

Esta escrita versa sobre a extensão criativa do Oitão Cênico, grupo fundado em fevereiro de 2009 na região do Cariri cearense e que desde sua gênese desenvolve uma linha de pesquisa e criação em continuidade, denominada de Sentir: índice criativo de uma poética cênica, gerada através de convivências na grupalidade, na busca de um fazer artístico pautado pela experimentação.

\footnotetext{
${ }^{1}$ Mauro Cesar é Ator e Diretor, no 769 DRT-CE. Mestre em Artes Cênicas pela Universidade Federal da Bahia - UFBA - CAPES (2018). Especialista Estudos Contemporâneos em Dança pela Universidade Federal da Bahia -UFBA (2016). Possui graduação em Letras (2006) e Especialização em Literatura Brasileira (2007) pela Universidade Regional do Cariri - URCA. Graduação em andamento no Programa Especial de Formação Pedagógica - Arte Educação/Centro Universitário UniGrande (2018).
}

ALVES, Mauro Cesar. Corpos constrangidos em potência de sentidos: rastros criativos do espetáculo cacos para um vitral - grupo oitão cênico - Cariri/CE. Revista da FUNDARTE, Montenegro, p.190211, ano 19, no 38, abril/junho de 2019.

Disponível em: http://.seer.fundarte.rs.gov.br/index.php/RevistadaFundarte/index> 28 de junho de 2019. 


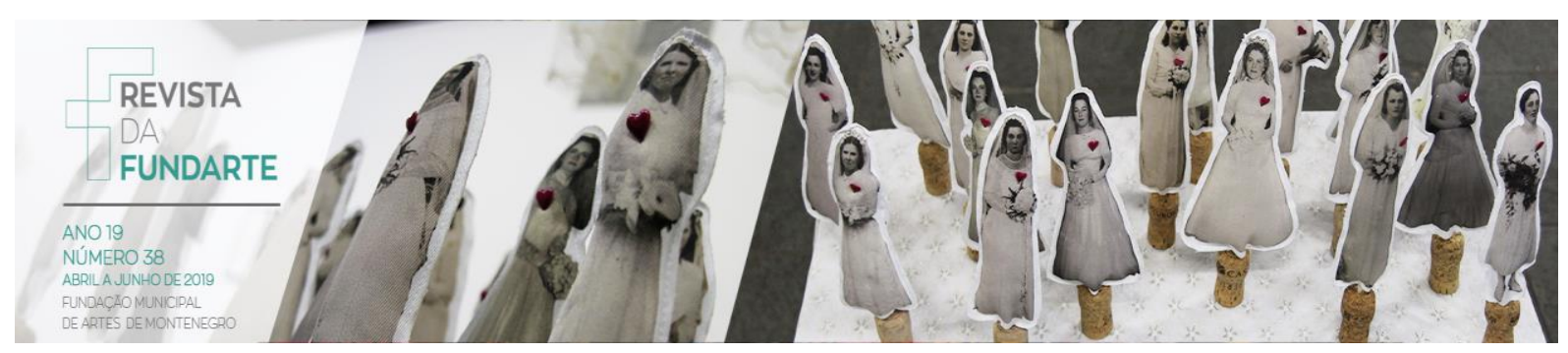

Quanto à escritura textual, os rastros do processo criativo do Oitão serão revisados com o apoio dos estudos da Crítica de Processos na perspectiva da pesquisadora Cecília Salles $(2004,2008)$, teoria que investiga a obra de arte a partir de sua construção, ponderando ciência e arte por meio de pistas deixadas por seus criadores, narrando a gênese da obra e demonstrando alguns princípios que possibilitaram a geração da mesma.

Como diretor e ator-performer do Grupo, passarei por uma narrativa performativa implicada, ou seja, uma discussão das subjetividades constitutivas das experiências presentes no processo de criação para o espetáculo, concebendo neste narrar a relevância da individuação, quer dizer, as percepções, hesitações, avanços e rompimentos dentro do jogo cênico em relação às escolhas poéticoestéticas na criação do espetáculo Cacos para um vitral.

A pesquisa nasce em função de observarmos que parte de nossas criações, como também as criações cênicas que assistíamos, de modo geral, não estabelecia um contágio comunicacional poroso com 0 público. Fundamentados nesta percepção, nos perguntamos como criar uma obra cênica em que o artista da cena ${ }^{2}$, e o público estivessem suspensos ${ }^{3}$ pelo sentimento em toda duração do espetáculo. Problema um tanto pretensioso, pois queríamos abarcar a suspensão, uma espécie de êxtase no decorrer de toda a encenação. Mas, para um grupo que estava iniciando, seria uma dentre tantas outras contradições.

Sendo assim, nossa primeira referência no desenvolvimento dos princípios estéticos de criação fundamenta-se na palestra $O$ poder humanizador da Poesia, da poetisa Adélia Prado. No final desta palestra há um bate-papo com a plateia, onde um espectador a questiona: "Você acha que hoje ainda é possível falar - sem falso

\footnotetext{
${ }^{2}$ Expressão que busca aglutinar o artista que transita pelas artes performativas: teatro, dança, circo, performance, etc.

${ }_{3}$ Dentre os significados do dicionário virtual HOUAISS para esta palavra, nos interessa nesta pesquisa a denotação de "estado de elevação espiritual e de fruição estética; enleio, êxtase."

ALVES, Mauro Cesar. Corpos constrangidos em potência de sentidos: rastros criativos do espetáculo cacos para um vitral - grupo oitão cênico - Cariri/CE. Revista da FUNDARTE, Montenegro, p.190211, ano 19, no 38, abril/junho de 2019.

Disponível em: http://.seer.fundarte.rs.gov.br/index.php/RevistadaFundarte/index> 28 de junho de 2019.
} 


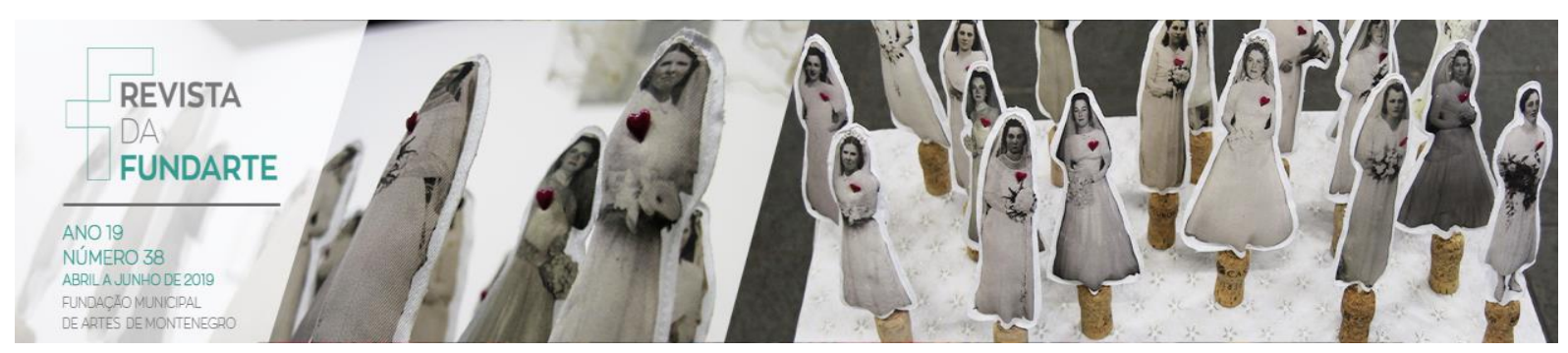

moralismo e sem hipocrisia - em uma educação dos afetos, em uma educação da sensibilidade?" A autora responde:

\begin{abstract}
Eu acho que precisa só disso, sabe? Precisa só disso. Porque a educação acadêmica formal está cuidando bem das disciplinas da área, vamos dizer assim. Porque você vê, por exemplo, pessoas muito bem formadas academicamente, que são completamente infelizes e descoordenadas quanto aos próprios afetos: pessoas de difícil relacionamento, pessoas tristes, infelizes, e toda a infelicidade e felicidade humana tem a ver com os afetos. Então é uma das vertentes que a escola descuida - quer dizer, a escola verdadeira teria, terá e tem que cuidar da educação da sensibilidade. [...] Eu acho que tudo mora na educação dos afetos: a fonte da infelicidade das pessoas é de natureza afetiva, sempre. A psicologia sabe disso e cuida só disso. Não é porque eu sei um teorema maravilhoso que eu estou feliz ou que eu vou ficar perturbada. É no afeto! Ninguém me ama, ninguém me quer, ninguém me chama de Baudelaire! É afeto, é afeto! Eu não amo! Eu não amo! Eu não me relaciono! Eu não perdoo! Eu não desejo! Eu não espero! Eu não sou compassivo! Eu não sou feliz e não permito que as pessoas sejam! É amor, é o centro! É por isso que eu acho que a educação pela arte educa a sensibilidade, porque a arte é amorosa, ela é fraterna, ela é amorosa, ela não exclui, ela não faz acepção de pessoas, ela puxa para si.
\end{abstract}

Esse discurso adeliano contribuiu para que buscássemos uma metodologia de trabalho no processo criativo do Oitão sob a circunspecção de uma educação dos afetos, em consonância com o problema megalomaníaco de 'como criar uma obra teatral em que o(a) artista da cena e o espectador estejam suspensos pelo sentimento em toda duração do espetáculo?' e, reformulei este problema no andamento do mestrado ao perguntar se 'é possível criarmos uma obra cênica em que a circulação afetiva entre o artista da cena e o púbico seja potencializada durante uma apresentação?'

Mas, quais os métodos existentes para uma educação dos afetos na criação cênica? Como não tínhamos referenciais naquele período, vou tentar situar nossas escolhas estético-metodológicas, para, talvez, respondermos esta questão.

Primeiro se faz necessário ponderarmos sobre o conceito de afetos na perspectiva do fazer cênico. No princípio da pesquisa, nossa principal referencia quanto ao tema abordado tratava-se de uma aula do filósofo Gilles Deleuze que

ALVES, Mauro Cesar. Corpos constrangidos em potência de sentidos: rastros criativos do espetáculo cacos para um vitral - grupo oitão cênico - Cariri/CE. Revista da FUNDARTE, Montenegro, p.190211, ano 19, no 38, abril/junho de 2019.

Disponível em: http://.seer.fundarte.rs.gov.br/index.php/RevistadaFundarte/index $>28$ de junho de 2019. 


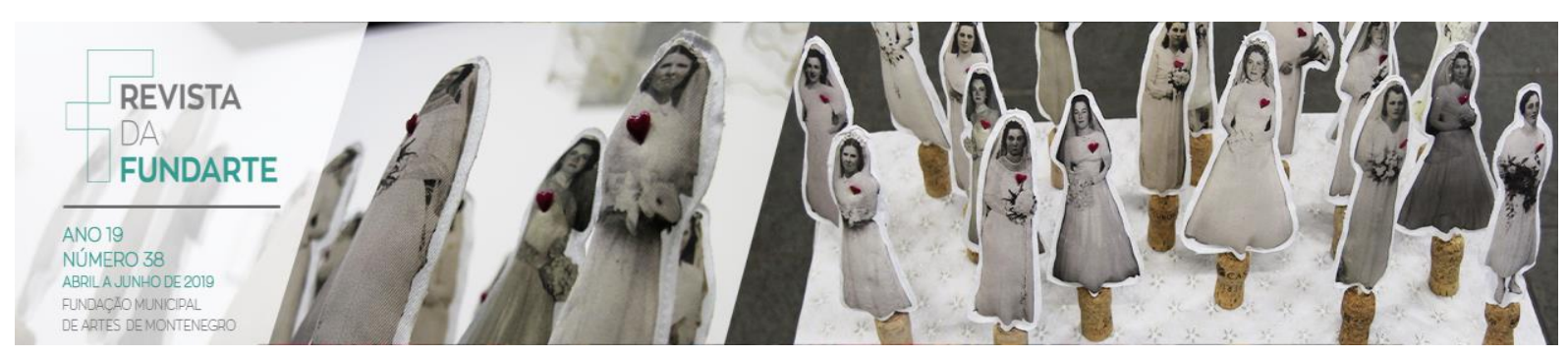

colaborou, minimamente, em abrir possibilidades discursivas ao "determinar o afeto (affectus) como a variação da potência de agir".

Concomitantemente ao processo criativo do Oitão, Ana Pais (2014), em sua tese de doutorado na Universidade de Lisboa/Portugal, intitulada Comoção: os ritmos afetivos do acontecimento teatral, esboça a teoria dos afetos e a performatividade dos afetos repensando a inter-relação cena/público a partir da dimensão afetiva na experiência teatral.

\begin{abstract}
Interdisciplinar e porosa nas suas fronteiras, a Teoria dos Afectos vem-se afirmando como campo de estudos na última década. Tendo por objecto de análise os afectos, naquilo que estes oferecem de radicalmente intangível, mas fundamental para o compreender as relações complexas entre corpo e mundo, esta teoria abre um espaço de reflexão sobre aspectos da experiência menorizados pela academia: os sentidos, as emoções e todas as formas sensíveis da experiência mediada pelo corpo, tendo em consideração os determinismos dos contextos mediatizados e tecnologicamente carregados, que constroem as formas de sentir. Sendo culturais e articulando-se nas relações sociais, económicas e políticas da sociedade, os afectos entendidos como forças presentes na relação com o mundo não podem ser totalmente compreendidas pelos instrumentos conceptuais de modelos estruturalistas, como a semiótica, ou por paradigmas racionalistas e científicos em que apenas o que é visível e comprovável oferece garantias de existência e de verdade. (PAIS, 2014, p. 58).
\end{abstract}

A autora busca retirar os afetos do âmbito místico em que costumeiramente se encontram no meio artístico e, colocá-los em uma perspectiva do conhecimento. Portanto, se abstém de utilizar a terminologia 'magia do teatro' e emprega o termo afetos. Posto isto, Pais teoriza o poder performativo da afetividade a partir do conceito de comoção que, segunda ela, "mais do que a catarse ou o potencial transformador das artes performativas, o fazer conjunto da comoção permite uma compreensão mais adequada à natureza complexa e inefável da experiência estética no teatro". (PAIS, 2014, p. 67)

Logo, importa dizer que a pesquisa sobre comoção procura repensar a interrelação cena/público no acontecimento teatral e de como políticas afetivas de obras

ALVES, Mauro Cesar. Corpos constrangidos em potência de sentidos: rastros criativos do espetáculo cacos para um vitral - grupo oitão cênico - Cariri/CE. Revista da FUNDARTE, Montenegro, p.190211, ano 19, no 38, abril/junho de 2019.

Disponível em: http://.seer.fundarte.rs.gov.br/index.php/RevistadaFundarte/index> 28 de junho de 2019. 


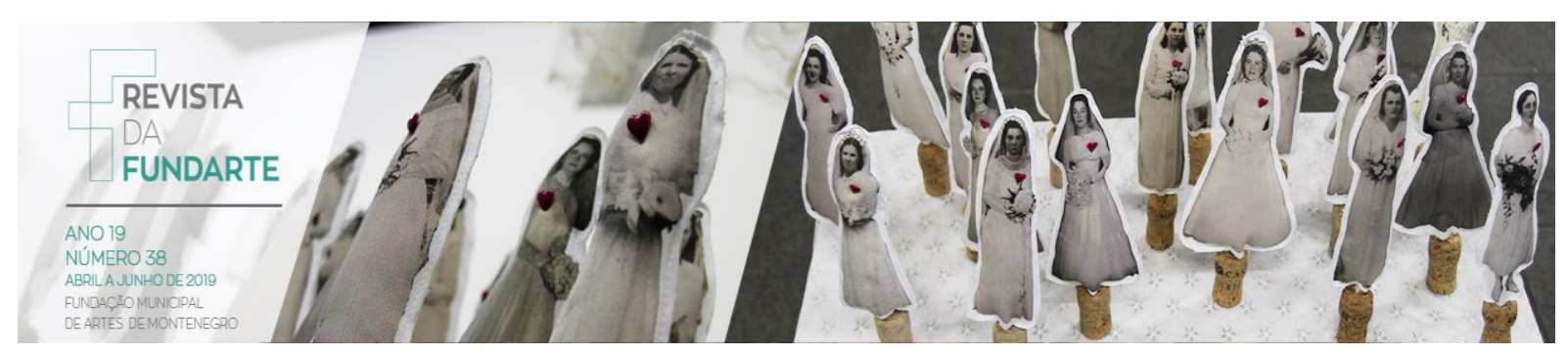

artísticas ao vivo podem condicionar ou potencializar a troca com o espectador e vice-versa.

Para esboçar a teoria dos afetos e a performatividade dos afetos, Ana Pais escolhe, respectivamente, a teoria da transmissão dos afetos de Teresa Brennan e a performatividade das emoções de Sarah Ahamed. A primeira problematiza 0 fenômeno na sua dimensão coletiva e biológica e a segunda proposta apresenta a construção e mediação entre mundo e sujeito do ponto de vista de uma política cultural das emoções.

A partir dessas perspectivas teóricas uma noção de afeto é elaborada por Ana Pais (2014), definindo-se afetos como cargas sensíveis que intensificam estados do corpo, circulam no meio social e são transportados por pensamentos, palavras, sensações e emoções. Ao passo que estamos constantemente emitindo e recebendo cargas sensíveis e, estas se manifestam através de sutilezas corporais, produzindo conhecimento tácito e individual.

Portanto, a teoria dos afetos adentra e elucida a implicação social que o Oitão busca estabelecer a partir da sensibilidade como princípio estético de criação, principalmente, ao abordar que essa teoria redimensiona o fazer cênico ao presumir sua performatividade no instante em que artistas da cena transportam para os processos criativos suas intensidades, transmitindo através de sensações, emoções, pensamentos e palavras, as cargas que circulam no meio social.

Durante a pesquisa de mestrado pude realizar um panorama dos princípios estético-poéticos na criação de nossas obras cênicas, bem como abordar as escolhas éticas e políticas que constituíram na formação do grupo Oitão. Contudo, como o tempo da investigação acadêmica stricto sensu é reduzida, deixei para ulteriores oportunidades aprofundar os procedimentos metodológicos de criação e o diálogo com outras poéticas da cena.

ALVES, Mauro Cesar. Corpos constrangidos em potência de sentidos: rastros criativos do espetáculo cacos para um vitral - grupo oitão cênico - Cariri/CE. Revista da FUNDARTE, Montenegro, p.190211, ano 19, no 38, abril/junho de 2019.

Disponível em: http://.seer.fundarte.rs.gov.br/index.php/RevistadaFundarte/index> 28 de junho de 2019. 


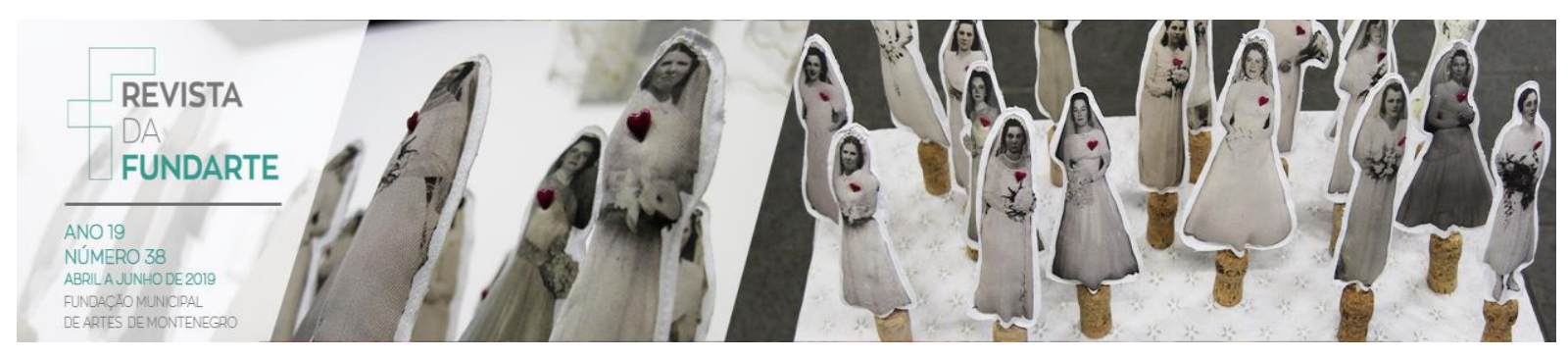

\section{A escolha dos cacos poéticos}

Iniciamos nossa investigação cênica em março de 2009. Os exercícios de sensibilização durante o processo criativo foram atravessados pelo viés do ator-atrizperformer, a palhaçaria e a exposição de experiências constrangedoras.

Nesse período, criamos cenas curtas que transitavam entre a teatralidade e a performatividade a partir da exposição de nossos constrangimentos pessoais e sociais. Josette Féral (2009, p. 209) aprofunda que "no teatro performativo, o ator é chamado a 'fazer' (doing), a 'estar presente', a assumir os riscos e a 'mostrar o fazer' (showing the doing), em outras palavras, a afirmar a performatividade do processo. [...] Uma estética da presença se instaura (se met en place)". Estar presente, assumir o risco... este "não lugar" (todo lugar): a situação limítrofe entre o épicotrágico e o líricocômico permeou o nosso processo de (des)construção, várias minicenas sobrepunham-se no êxtase de uma poético dos afetos. Algumas dessas cenas curtas foram apresentadas em agosto de 2009, quando participamos do Festival de Teatro em Acopiara/FETAC, apresentando alguns experimentos, como 0 caso do solo na Na Ponta do Pé de Alan Oliveira.

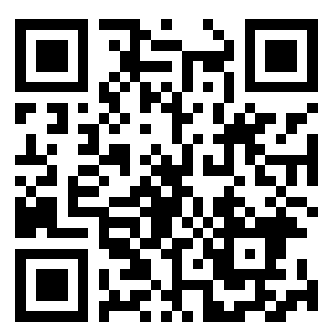

Figura 1 - Código QR: Esquete 'Na ponta do Pé' $<$ https://www.youtube.com/watch? $v=v N 2 d o l t L x X w>$

Abrir a cena, seminu, em frenesi descompassado à sonoplastia do samba em que as expressões faciais remetem a dor, contrastando com as do corpo, reverberam os paradoxos e fazem desta composição cênica um coagulo de suspensão de sentimentos e emoções no público, causando um silêncio constrangedor. À medida que a cena se desenrola, a sonoplastia se intensifica e o

ALVES, Mauro Cesar. Corpos constrangidos em potência de sentidos: rastros criativos do espetáculo cacos para um vitral - grupo oitão cênico - Cariri/CE. Revista da FUNDARTE, Montenegro, p.190211, ano 19, № 38, abril/junho de 2019.

Disponível em: http://.seer.fundarte.rs.gov.br/index.php/RevistadaFundarte/index> 28 de junho de 2019. 


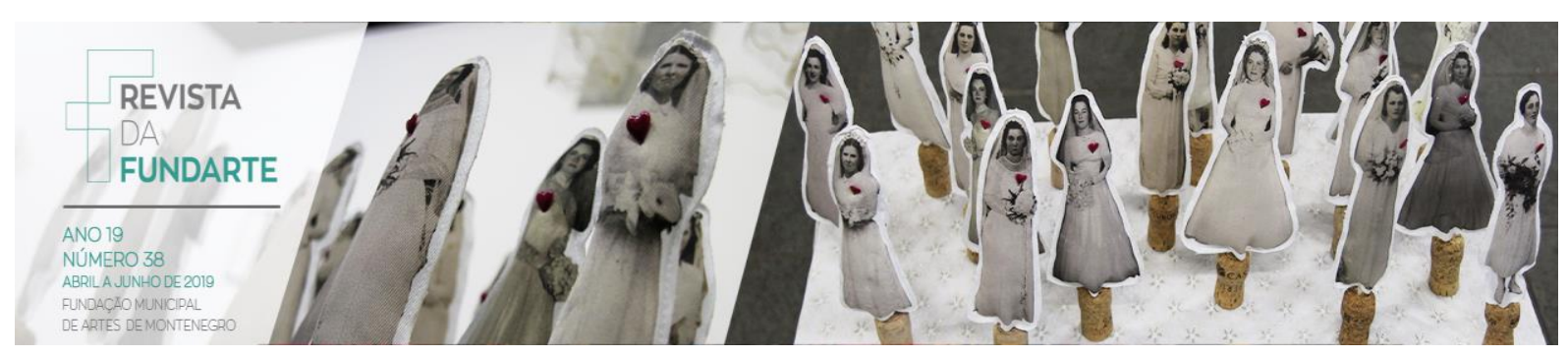

ator-performer, que incialmente encontrava-se seminu, constrói externamente sua personagem (vestindo peças de roupas). Internamente essa reconstrução se dá ao sincronizar música/expressão corporal/expressão facial. Não por acaso, na última peça posta - a peruca; ápice da cena é, também, o único momento de manifestação da plateia: do caos surge o cosmo.

Esses primeiros experimentos tinham por objetivo, para além de acessarmos nossa afetividade constrangida, verificarmos a recepção do público através desses fractais cênicos. Percebemos que a comunicação se estabelecia de forma porosa, nos encorajando seguir o trajeto investigativo que escolhemos.

Buscamos, pois, na constituição dessa poética, darmos visibilidade ao sentir, um trabalho de construção cênica a partir de experimentações em que memórias constrangedoras eram expostas dando grafias aos afetos através do corpo enquanto canal de um empoderamento do sujeito sobre suas emoções, seu autoconhecimento e, consequentemente, concedendo lugar à cena como locus de uma experiência do momento.

A estética do momento contaminou de sobremaneira nossas escolhas poético-estéticas. Sobretudo uma proposta elaborada por J. L. Moreno no livro $O$ Teatro da Espontaneidade (1973), a mesma obra em que um dia sonhei com uma voz me pedindo para eu lê-la.

O contraste entre o teatro tal como conhecemos e o teatro da espontaneidade reside no tratamento diferencial que ambos dispensam do momento. O primeiro tenta apresentar seus produtos perante uma audiência, como criações acabadas e definidas; o momento é ignorado. $O$ último busca o próprio momento e, de um só golpe, criar a forma e o conteúdo do drama na qualidade de partes integrais do mesmo. (MORENO, 1973, p. 51).

O teatro da espontaneidade ou do momento se contrapõe ao materialismo exacerbado do início do século XX e, também, em protesto à 'conserva cultural' que incluía os produtos acabados do drama, pois seria uma criação realizada no passado por meio de textos prontos, ensaiados e apresentados ao público como

ALVES, Mauro Cesar. Corpos constrangidos em potência de sentidos: rastros criativos do espetáculo cacos para um vitral - grupo oitão cênico - Cariri/CE. Revista da FUNDARTE, Montenegro, p.190211, ano 19, no 38, abril/junho de 2019.

Disponível em: http://.seer.fundarte.rs.gov.br/index.php/RevistadaFundarte/index> 28 de junho de 2019. 


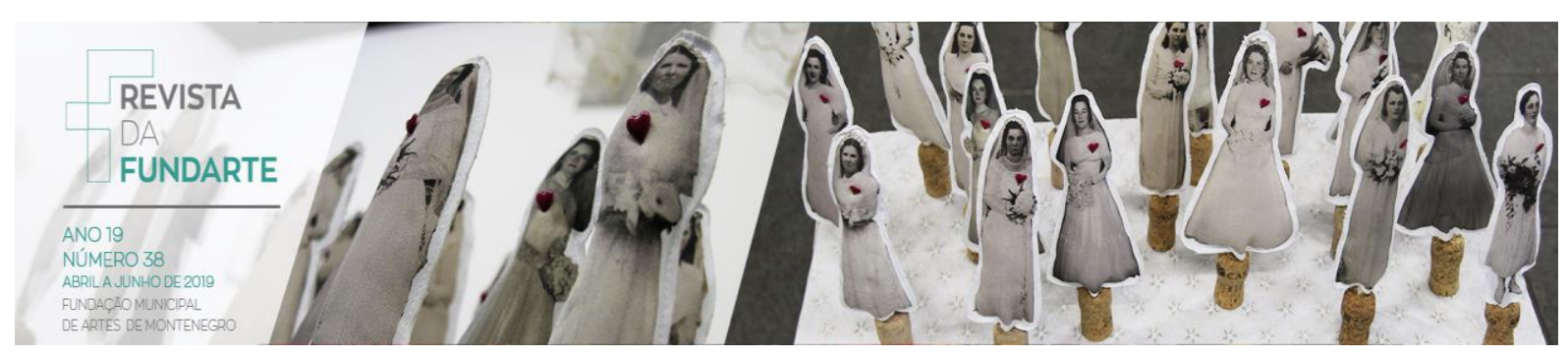

produto do presente, deixando os atores desprovidos de criatividade para o momento de sua atuação.

A primazia do teatro da espontaneidade está no eu (self) do ator e sua criatividade. Depois de alguns anos pesquisando a espontaneidade a nível experimental através do teatro com atores, não-atores e os próprios espectadores, a tese de Moreno (1973, p. 20) afirma que "o locus do eu está na espontaneidade [...] Conforme declina a espontaneidade, murcha o self. Quando a espontaneidade cresce, o eu se expande. Uma é função da outra."

Moreno aponta duas importantes descobertas de sua pesquisa ao identificar que a espontaneidade está intrinsicamente conectada ao eu (self) e 'pode ficar rançosa', caso não prestemos atenção no seu desenvolvimento e a controlemos a partir da interioridade. Como exemplo, é citado o caso de atores que transformam aspectos da espontaneidade em clichês. A segunda descoberta induz que independentemente da chama inicial da espontaneidade em um ser, ela pode ser treinada, nesse caso, sugiro a leitura do livro O Teatro da Espontaneidade, onde o autor apresenta os princípios para esse treinamento e o desenvolvimento da espontaneidade criativa.

Ao tratar da dimensão do self, Moreno abaliza que a humanidade se adaptou facilmente na utilização dos meios tecnológicos, como em utilizar um pedaço de pau, uma bomba atômica. No entanto, no plano social, na prontidão para adaptar-se aos meios que lhe asseguram a liberdade no âmbito social, a competência é muito baixa. Então, podemos perguntar, por que será que há um descompasso na evolução humana entre os termos sociais e tecnológicos? A tentativa de resposta do teatrólogo romeno implica no seguinte aspecto:

\footnotetext{
Não é fácil apresentar respostas a esta dificuldade; o homem precisa ser educado; aqui, educação implica mais do que o mero esclarecimento intelectual, não se trata apenas de deficiência na inteligência e é mais do que esclarecimento emocional; não é apenas uma questão de insight, mas, ao contrário, é um problema de deficiência na espontaneidade de se usar a inteligência disponível e de se mobilizar as emoções esclarecidas. Um tal programa de preparo, contudo, requer treinamento dos homens, requer o treino e a reciclagem de treinamento dos homens numa escala mundial,
}

ALVES, Mauro Cesar. Corpos constrangidos em potência de sentidos: rastros criativos do espetáculo cacos para um vitral - grupo oitão cênico - Cariri/CE. Revista da FUNDARTE, Montenegro, p.190211, ano 19, no 38, abril/junho de 2019.

Disponível em: http://.seer.fundarte.rs.gov.br/index.php/RevistadaFundarte/index> 28 de junho de 2019. 


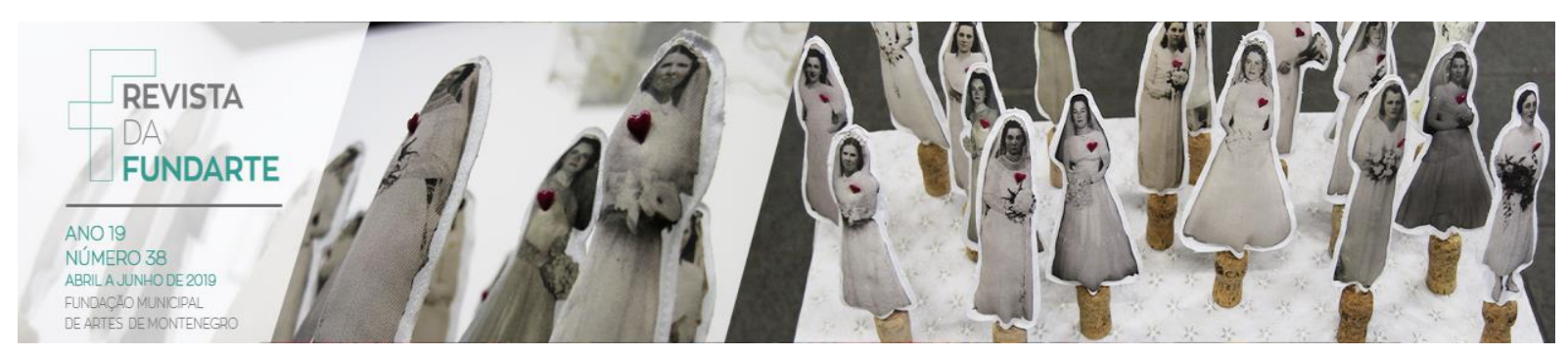

dentro dos parâmetros de espontaneidade; requer uma pesquisa de ação e métodos de ação que continuamente se modifiquem e se aperfeiçoem para serem enfrentados novos ambiente internos e externos. (MORENO, 1973, p. 23).

Para tanto, um ponto relevante desse processo versa sobre a tentativa de expormos os constrangimentos que no dia a dia nos impediam de sermos quem de fato somos, assumindo nossas fragilidades na criação cênica, reencontrando brechas para o exercício da espontaneidade que outrora fora perdida.

Nesse aspecto, outra contribuição da obra de Moreno reporta-se quando o psiquiatra exibe os fundamentos do teatro terapêutico, ao articular que este emerge do lar particular do indivíduo, "do mais profundo sentido, pois os segredos mais resguardados resistem violentamente a um contato ou a uma exposição". (MORENO, 1973, p. 105).

Inspirados por essa afirmativa e com o intuito de darmos resposta ao nosso problema inicial de 'como potencializar a circulação afetiva no ambiente da cena entre o(a) artista de cena e o público?', intuíamos em expor 'os segredos mais resguardados', pois, talvez, em nossos corpos, com suas informações sentidas e constrangidas, poderíamos transformar essas marcas da experiência em potência recriadora da cena.

Aporta neste aspecto a participação do Oitão em um retiro para descoberta dos nossos palhaços, de forma a estimular os trabalhos palhacísticos do grupo, ampliando os nossos procedimentos de criação. Pondo em prática os ensinamentos vivenciados no retiro, optamos por vivenciá-los através de uma intervenção urbana intervimos por alguns minutos junto aos transeuntes da Praça Cristo Rei na cidade do Crato, fizemos o trajeto de $22 \mathrm{~km}$ em transporte coletivo e aportamos na última parada na praça Pe. Cícero em Juazeiro do Norte. Expor o palhaço inerente a cada um é também um convite ao interlocutor para que o palhaço dele se manifeste; a receptividade do palhaço em nós visitou os extremos das sensações alheias.

ALVES, Mauro Cesar. Corpos constrangidos em potência de sentidos: rastros criativos do espetáculo cacos para um vitral - grupo oitão cênico - Cariri/CE. Revista da FUNDARTE, Montenegro, p.190211, ano 19, № 38, abril/junho de 2019.

Disponível em: http://.seer.fundarte.rs.gov.br/index.php/RevistadaFundarte/index> 28 de junho de 2019. 


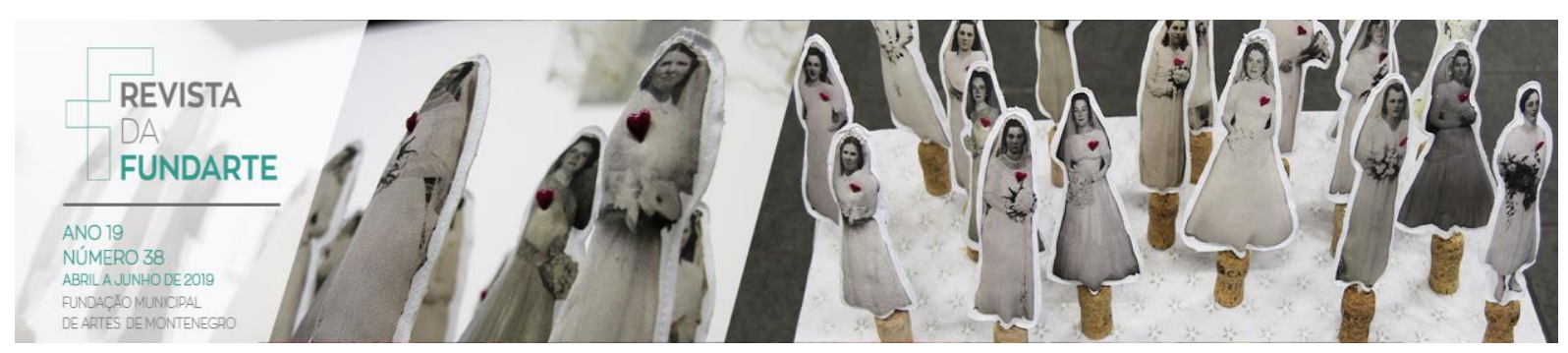

Recebemos do asco ao afeto, do constrangimento à aceitação, do incomodo à galhofa.

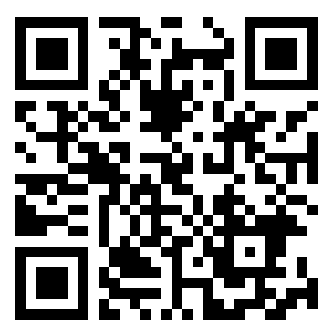

Figura 2 - Código QR: Intervenção Urbana 'Buzu Teatro' $<$ https://www.youtube.com/watch?v=VT7LNDKfiXY>

Como vemos, o retiro de palhaço nos proporcionou ferramentas a partir da técnica para descoberta do palhaço, utilizamos esses procedimentos com fins performativos na elaboração e projeção do ridículo.

O ridículo é percebido por nós, não só como o que gera a espontaneidade e o riso, mas também, é um reflexo da ignorância humana sobre si mesmo. Portanto, a ridicularização se transformou em uma ferramenta poética e de autoconhecimento, revelando algumas fragilidades que no cotidiano tentávamos esconder de nossos pares, optamos em assumir essas ditas 'imperfeições', transformando-as em poesia.

\section{Servidão versus Liberdade: cacos de uma vida}

$\mathrm{Na}$ procura por contribuições que ratificassem esse fazer, ainda em 2010, assisti a uma palestra em vídeo do filósofo e professor fluminense Claudio Ulpiano. $\mathrm{Na}$ época, o conteúdo me apresentou, de relance, ao pensamento de Spinoza e, fiz algumas anotações que introduziam a acepção de servidão e liberdade para compartilhar com os membros do Oitão.

ALVES, Mauro Cesar. Corpos constrangidos em potência de sentidos: rastros criativos do espetáculo cacos para um vitral - grupo oitão cênico - Cariri/CE. Revista da FUNDARTE, Montenegro, p.190211, ano 19, № 38, abril/junho de 2019.

Disponível em: http://.seer.fundarte.rs.gov.br/index.php/RevistadaFundarte/index> 28 de junho de 2019. 

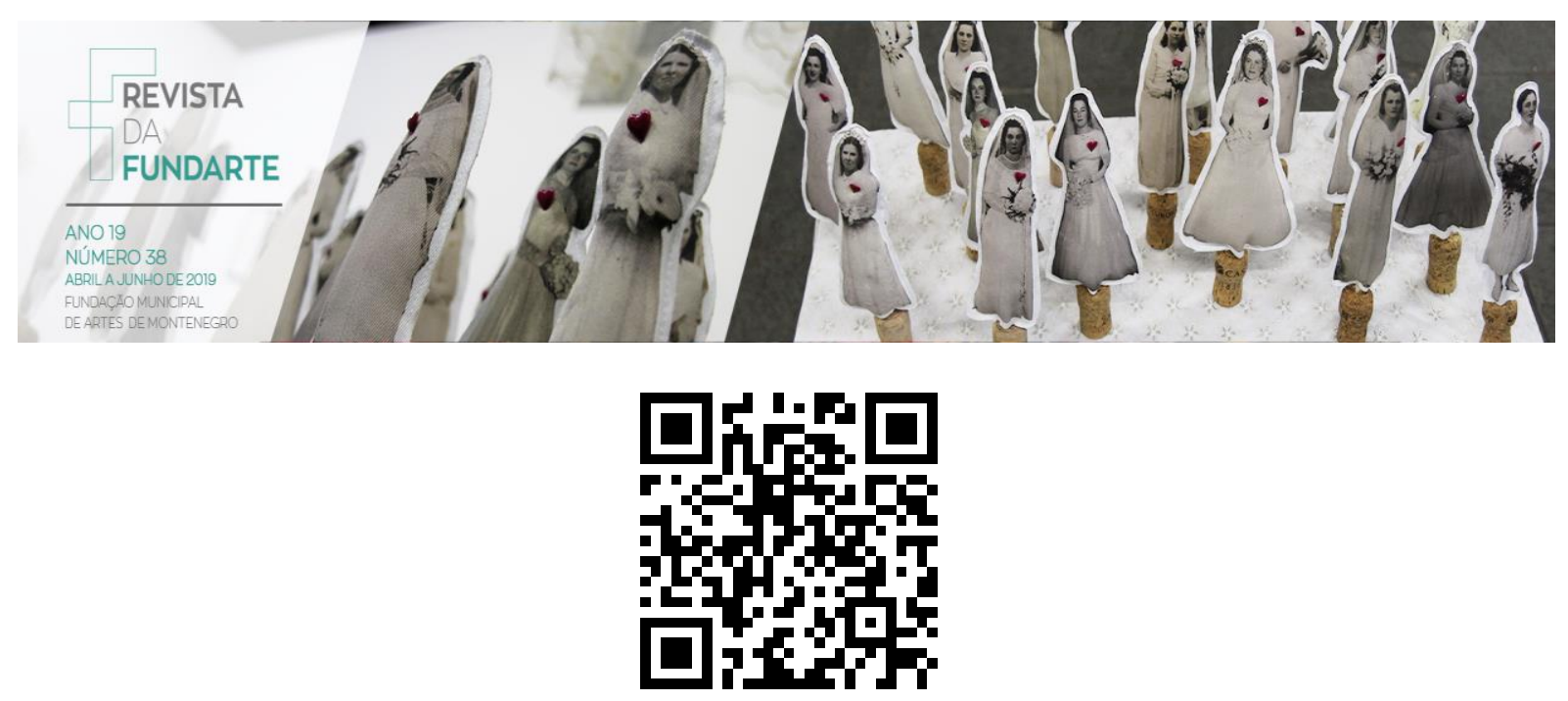

Figura 3 - Código QR: Palestra 'Pensamento e Liberdade em Spinoza' $<$ https://www.youtube.com/watch?v=oBDEZSx6xVs>

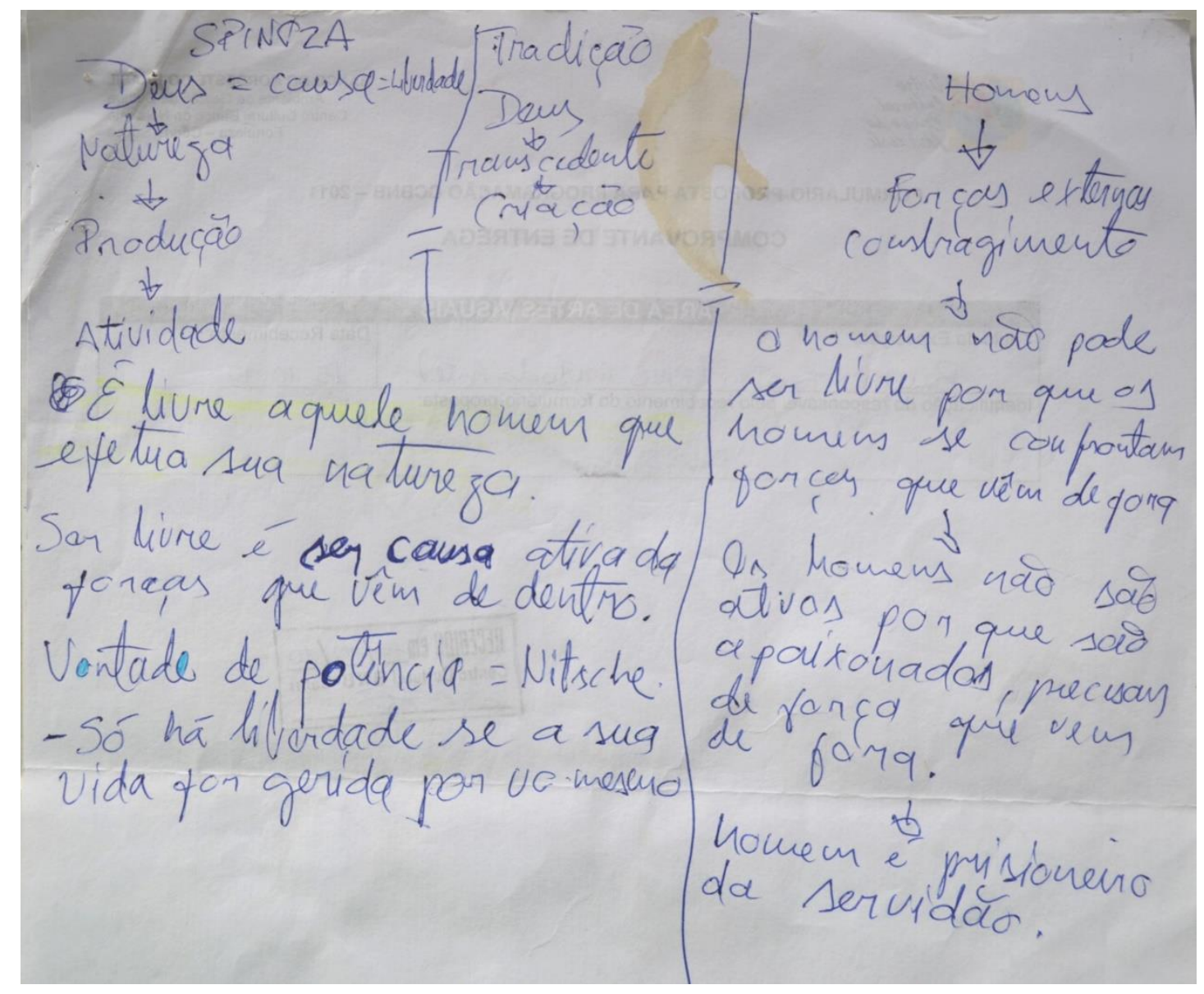

Figura 4 - Anotações feitas por mim, em um dia qualquer de 2010 em Caririaçu/CE. Assisti por meio de vídeo VHS, emprestado pelo amigo Jackson Gouveia.

ALVES, Mauro Cesar. Corpos constrangidos em potência de sentidos: rastros criativos do espetáculo cacos para um vitral - grupo oitão cênico - Cariri/CE. Revista da FUNDARTE, Montenegro, p.190211, ano 19, no 38, abril/junho de 2019.

Disponível em: http://.seer.fundarte.rs.gov.br/index.php/RevistadaFundarte/index> 28 de junho de 2019. 


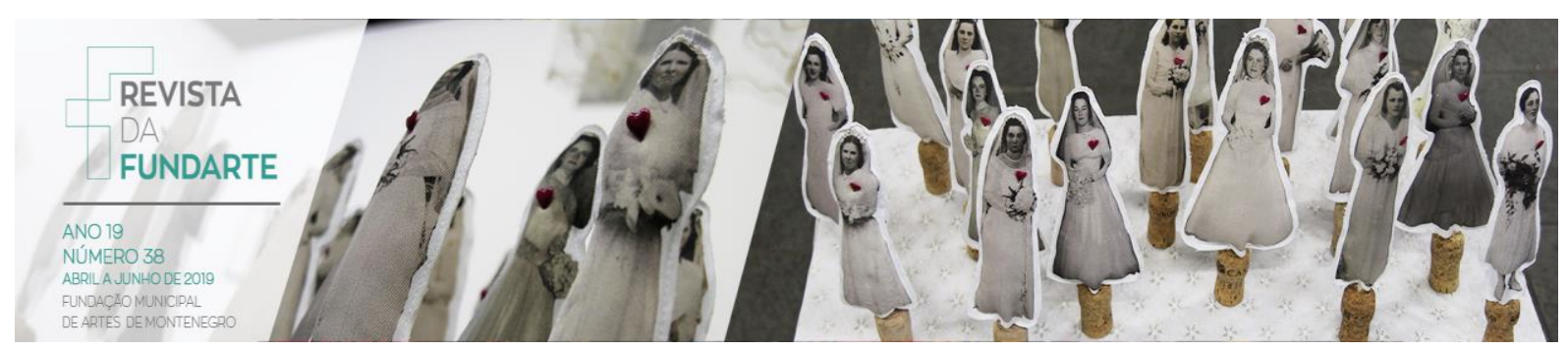

Para Spinoza, Deus é causa em contínua atividade e produção, exerce sua liberdade de dentro para fora ao passo que se manifesta na natureza, sendo causa ativa das forças que vêm de dentro. Do ponto de vista da tradição, a compreensão de Deus está conectada ao transcendente, de algo exterior a mim, um Deus que criou homens e mulheres e, portanto, uma força externa e constrangedora que moldou a criação. Sobre os conceitos de servidão e liberdade do homem, na introdução do quarto capítulo do livro Ética, Spinoza define as forças dos afetos alegres e tristes dizendo: "Chamo de servidão a impotência humana para regular e refrear os afetos." (SPINOZA, 2009, Parte IV, prefácio) e por isso, toda vez que o homem não age por sua natureza, ele está sendo constrangido por forças (paixões) que vêm de fora. Segundo o filósofo, se constitui livre o homem cuja força é ativa de sua natureza e age através das forças que vêm de dentro.

Enquanto seres inconclusos, vivemos em meio às condições dadas pela natureza, assim como aquelas que são socioculturalmente criadas por nós. No entanto, a humanidade se depara com uma formação social basicamente de princípios materialistas e, por isso mesmo, temos evoluído drasticamente na esfera tecnológica por meio da força do capitalismo para atender aos interesses dos detentores dos meios de produção e, estes por sua vez, oferecem às classes proletariadas um circuito de afetos orquestrado pelas paixões calcadas no medo, principalmente, o medo que condiciona o sujeito a uma tensão constante pela busca do mais trivial da vida humana: a sobrevivência.

A partir dessa necessidade vital, o sistema submete indivíduos a trabalhos que menosprezam a capacidade humana de sentir e criar, nossa finalidade única nessa engrenagem se restringe ao trabalho, consumo e, quem sabe, acumular. Infelizmente, ao grande número de sujeitos marginalizados por esse processo, existe a condição da miséria. E, sob esse círculo vicioso, o capital nos mantém na ignorância como garantia da servidão humana.

ALVES, Mauro Cesar. Corpos constrangidos em potência de sentidos: rastros criativos do espetáculo cacos para um vitral - grupo oitão cênico - Cariri/CE. Revista da FUNDARTE, Montenegro, p.190211, ano 19, no 38, abril/junho de 2019.

Disponível em: http://.seer.fundarte.rs.gov.br/index.php/RevistadaFundarte/index> 28 de junho de 2019. 


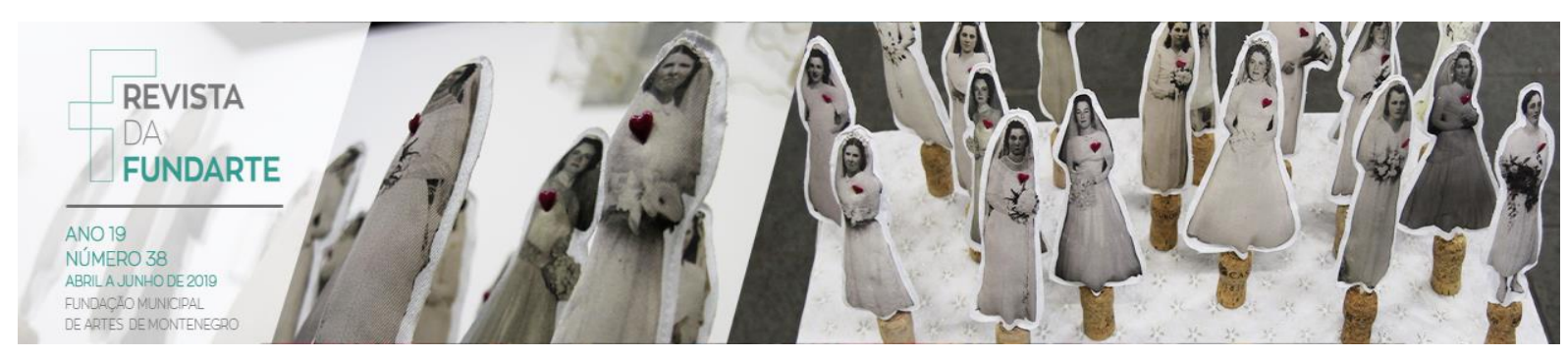

Logo, para Spinoza, a liberdade se manifesta quando a razão começa a pesar os afetos e aprende a refreá-los, medi-los e moderá-los para que não sejamos autômatos espirituais, ou seja, seres inconscientes, obedecendo à vontade alheia, sem refletirmos sobre nossos próprios atos.

Por conseguinte, Moreno (1973) ao discorrer sobre as relutâncias que a humanidade tem em se adaptar aos meios que possam assegurar sua liberdade em sociedade, exatamente porque houve um excessivo e rápido avanço tecnológico, e, conjuntamente, a secularização das instituições ao ponto de torná-las sagradas. 0 teatrólogo propõe que para acontecer uma crescente expansão do eu (self) será necessário que esta mesma humanidade retroceda até chegar ao plano sagradoespiritual, nesse caso, trata-se de um processo de não engenharia tecnológica, mas sim, de uma expansão do self pelo self, um programa de liberação do poder criativo e espontâneo a nível individual para o plano cósmico. Haverá, portanto, a busca por equilibrar os extremos quanto aos métodos de realização tanto dos santos, quanto dos cientistas.

Referenciado por essa perspectiva, pergunto-me, como podemos exercitar nossa liberdade mediante ao progresso tecno-ilógico'? Como criar possibilidades que se rebelem conscientemente ao modus vivendi que nos foi imposto? Como exercer a espontaneidade criativa de seres que foram constrangidos ao medo de desempenhar as forças que vêm de dentro?

Com a pergunta "O que pode um corpo?", Deleuze aponta para a natureza das inquietações do livro Ética quando Spinoza (2009, Ética III, Prop. 2) pondera que ninguém determinou pela experiência o que o corpo, enquanto lei da natureza, considerado apenas como corpo, pode ou não fazer. Redimensiono a questão de Deleuze ponderando o seguinte: o que pode um corpo quando ele se conscientiza que está na servidão e passa a exercer sua liberdade?

ALVES, Mauro Cesar. Corpos constrangidos em potência de sentidos: rastros criativos do espetáculo cacos para um vitral - grupo oitão cênico - Cariri/CE. Revista da FUNDARTE, Montenegro, p.190211, ano 19, no 38, abril/junho de 2019.

Disponível em: http://.seer.fundarte.rs.gov.br/index.php/RevistadaFundarte/index> 28 de junho de 2019. 


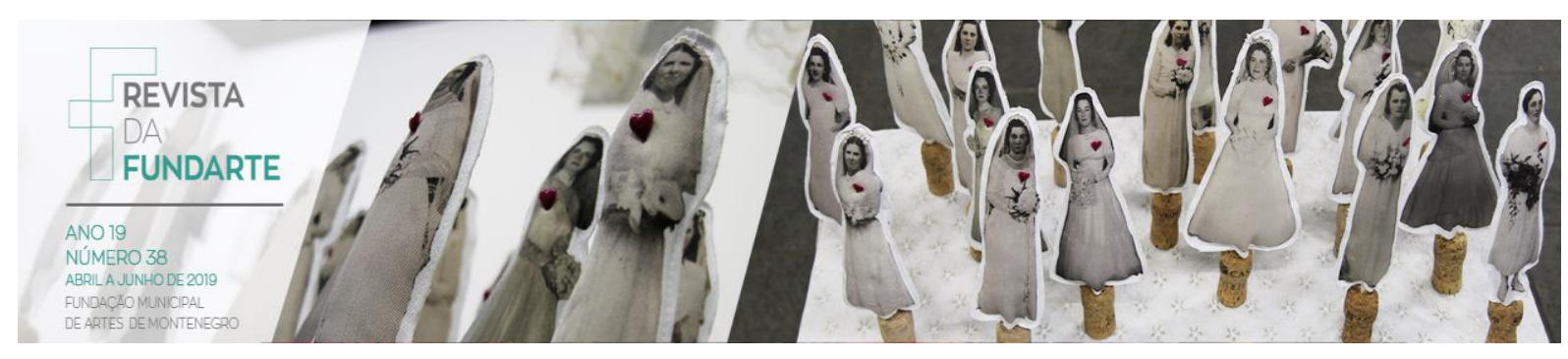

\section{Cacos pra um vitral: o espetáculo}

Em fevereiro de 2011 resolvemos criar um espetáculo e, o processo de Cacos para um vitral foi uma tentativa poética de se contrapor à servidão humana na procura pela almejada liberdade e tentar exercê-la minimamente na cena, quiçá, na vida. Partimos das experimentações que já havíamos desenvolvido no percurso de dois anos. No Festival de Teatro em Acopiara tivemos a oportunidade de apresentarmos uma coletânea dessas experimentações em agosto de 2009, com o título Oitão em Cena.

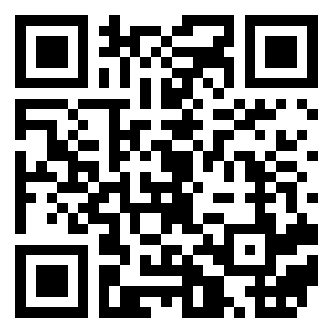

Figura 5 - Código QR: Experimento 'Oitão em Cenas' $<$ <ttps://www.youtube.com/watch?v=EMe3c1DtoMg>

Antes de entrarmos na construção dramatúrgica propriamente dita da encenação de Cacos para um vitral, realizamos um esvaziamento de todas as questões constrangedoras pessoais e sociais que queríamos expor, purgar na cena e, coletivamente, fomos catando esses pedacinhos de coisas guardadas dentro de nós; trabalho árduo e vagaroso, pois a "estória", até então estava fora do tempo e do espaço, e cabia ao ator-performer-pesquisador o dever de cada encontro confirmar ou negar sua vontade de revelá-la.

Após esse mergulho em nossas afetividades constrangedoras, nomeamos Adélia Prado e Cida Moreira como porta-vozes da dramaturgia que queríamos desenvolver, por conseguinte, selecionamos por afinidade fragmentos de poemas e músicas que gostaríamos que fizessem parte dessa "estória". Vasculhamos a

ALVES, Mauro Cesar. Corpos constrangidos em potência de sentidos: rastros criativos do espetáculo cacos para um vitral - grupo oitão cênico - Cariri/CE. Revista da FUNDARTE, Montenegro, p.190211, ano 19, № 38, abril/junho de 2019.

Disponível em: http://.seer.fundarte.rs.gov.br/index.php/RevistadaFundarte/index> 28 de junho de 2019. 


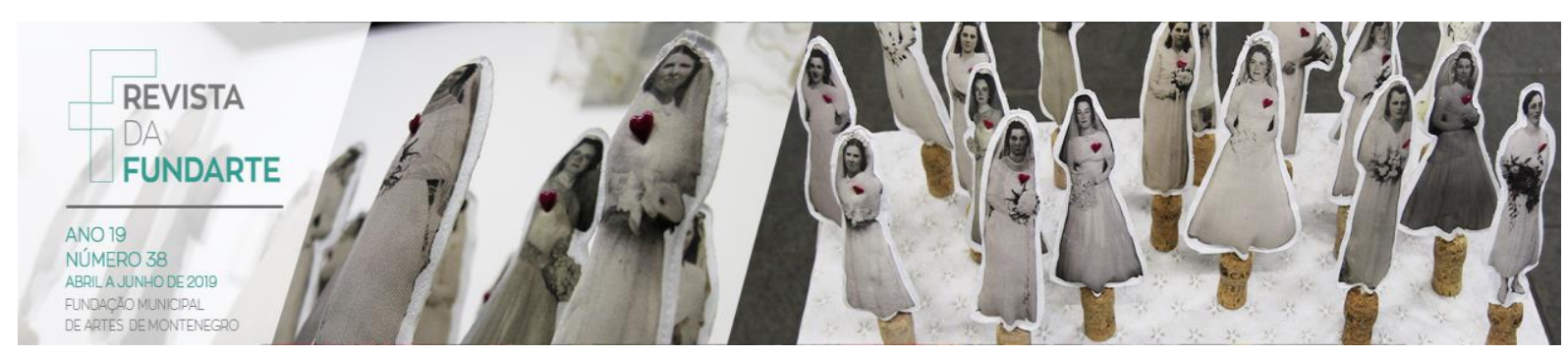

poesia ${ }^{4}$ adeliana e, na sequência, escolhemos fragmentos da obra fonográfica da atriz, pianista e cantora Cida Moreira ${ }^{5}$.

Com essa gama de material, chegou o momento de colarmos as cenas que já havíamos criado aos trechos de poemas e músicas; ainda produzimos algumas microcenas em que o próprio material poético e fonográfico nos conduzia na criação.

Optamos por esse tipo de abordagem com o objetivo de vivenciarmos as sinuosidades do processo criativo, pois estando em contato com essa materialidade cênica, nos tornávamos seguros dos propósitos trazidos à cena e dávamos caráter documental à criação poética. Sobre o que decanta dessa fase, Cecilia Almeida Salles pontua:

Outra função desempenhada pelos documentos de processos é a de experimentação, deixando transparecer a natureza intuitiva da criação. Nesse momento de concentração da obra, hipóteses de natureza diversas são levantadas e vão sendo testadas. Encontramos experimentação em rascunhos, estudos, croquis, plantas, esboços, roteiros, maquetes, copiões, projetos, ensaios, contatos, story-boards. Mais uma vez a experimentação é comum, as singularidades surgem nos princípios que direcionam as opções. (SALLES, 2014, p.18).

No período de um ano e meio, realizamos um trabalho artesanal: maceramos, peneiramos e extraímos o sumo de cada coisa, transformando-as cenicamente, fazendo surgir, assim, o registro de uma possível dramaturgia corpo-textual e musical que fala de todos e ao mesmo tempo de um só. Todas as cenas compostas

\footnotetext{
${ }^{4}$ Nos Livros Antologia Poética (1991), Oráculos de Maio (1999), Duração do dia (2010) e Miserere (2013), como também, em seus dois CDs gravados pelo selo Karmim: O tom de Adélia Prado, de 2000, onde ela lê poemas do livro Oráculos de maio e o CD, de 2003, O Sempre Amor, com recitação de alguns de seus poemas de amor.

${ }^{5}$ Através dos álbuns: Summertime (1981) Áudio Patrulha/Lira Paulistana-LP, Abolerado blues (1983) Lira Paulistana/Continental-LP, Cida Moreira (1986) Continental/LP-CD, Cida Moreira interpreta Brecht (1988) Continental-LP, Cida Moreira canta Chico Buarque (1993) Kuarup-CD, Balada do Louco (1996) Continental-CD, Na trilha do cinema (1997) Kuarup-CD, Uma Canção Pelo Ar... (2003) Kuarup-CD, Angenor (2008) Lua Music-CD, A Dama Indigna (2011) e Soledade (2015), ambos pela Joia Moderna-CD.
}

ALVES, Mauro Cesar. Corpos constrangidos em potência de sentidos: rastros criativos do espetáculo cacos para um vitral - grupo oitão cênico - Cariri/CE. Revista da FUNDARTE, Montenegro, p.190211, ano 19, no 38, abril/junho de 2019.

Disponível em: http://.seer.fundarte.rs.gov.br/index.php/RevistadaFundarte/index> 28 de junho de 2019. 


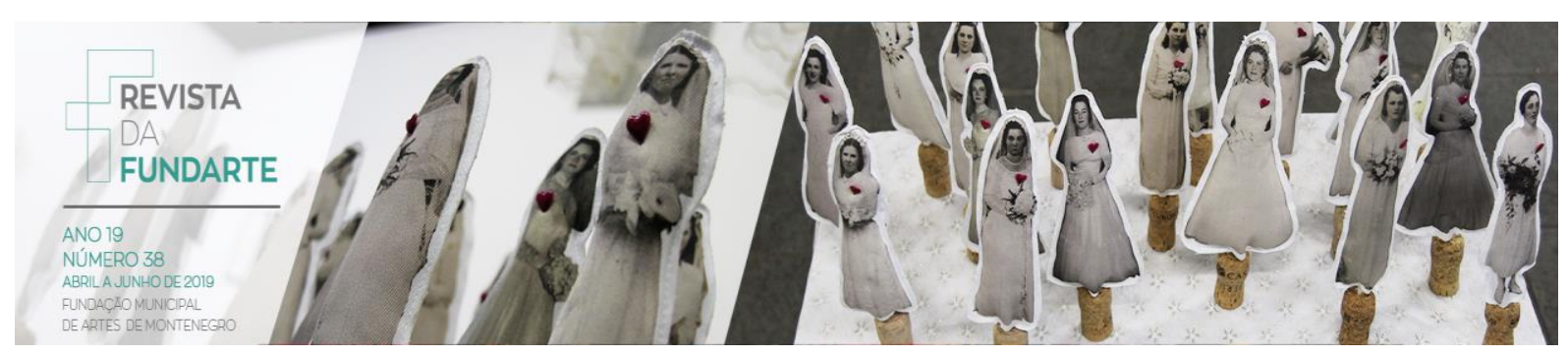

pelo viés da teatralidade e da performatividade se caracterizam pela manutenção da ação cênica como foco e com pouquíssimos recursos de narratividade.

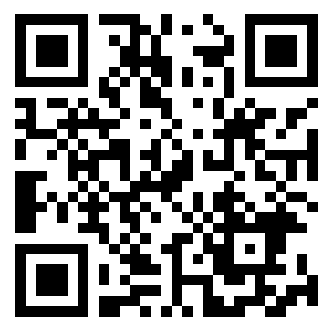

Figura 6 - Código QR: Espetáculo Cacos para um vitral - Agosto de $2014^{6}$ $<$ https://www.youtube.com/watch?v=VWgUdgGEuIM>

Desde a estreia realizada em abril de 2014, na VI Semana D da Dança Cariri, tivemos algumas paradas e retornos com o trabalho, mudando alguns aspectos da concepção cênica. Uma encenação aberta e em contínuo processo colaborativo, a peça aborda a exposição dos constrangimentos pessoais e socais dos(as) performers. Trata-se dos cacos de uma vida que queremos no dia a dia varrer para baixo do tapete. São afetos presentificados repercutindo em nossos corpos, de modo a transformar experiência em poética.

A encenação de Cacos para um vitral tem título homônimo de um poema da autora Adélia Prado, e também de uma de suas prosas, escrita em 1980. Como foram cinco anos de pesquisa e experimentações para estrearmos esse trabalho, o título faz inferência à grande quantidade de material cênico fragmentado que criamos no decorrer dos procedimentos artísticos. Sendo assim, nos dedicamos em conceber um espetáculo e gerar uma dramaturgia que pudesse comportar a demanda de material produzido.

Mediante vários elementos cênicos utilizados em nossas experimentações, selecionamos o uso do talco na procura por gerar unidade na encenação, um

\footnotetext{
${ }^{6}$ Gravação da sexta apresentação do espetáculo Cacos para um vitral, realizada no Centro Cultural Banco do Nordeste - CCBNB/Cariri. Em cena, Alan Oliveira, Edmilson Soares, Mauro Cesar e Suzana Carneiro. Na operação de som João Heriberto e de iluminação Raquel Morais.
}

ALVES, Mauro Cesar. Corpos constrangidos em potência de sentidos: rastros criativos do espetáculo cacos para um vitral - grupo oitão cênico - Cariri/CE. Revista da FUNDARTE, Montenegro, p.190211, ano 19, № 38, abril/junho de 2019.

Disponível em: http://.seer.fundarte.rs.gov.br/index.php/RevistadaFundarte/index> 28 de junho de 2019. 


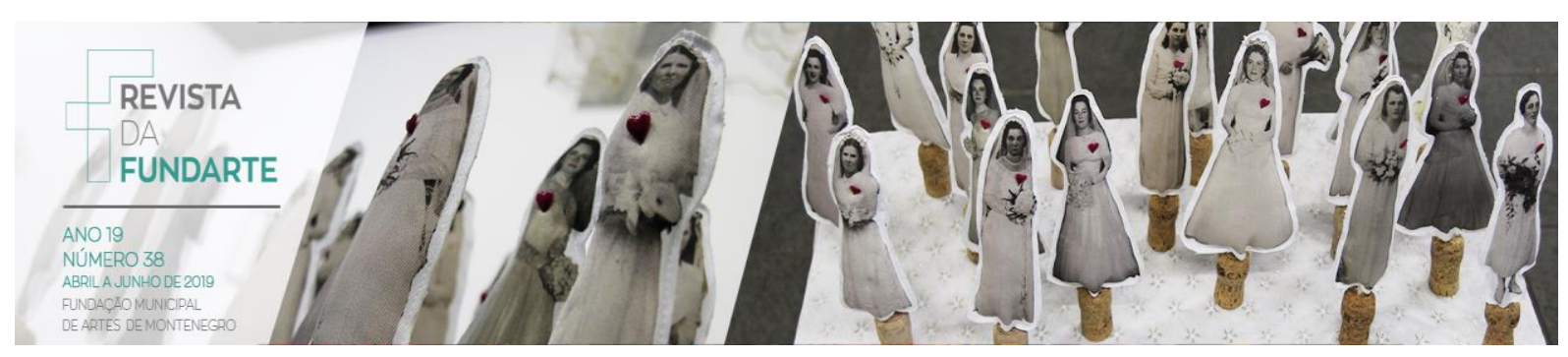

recurso metafórico que ao longo do espetáculo se transforma em água, areia, maquiagem e, nos possibilita o entendimento de algo transparente ao evidenciar nossas ações. O cheiro do talco nos remete ao universo da criança, aguçando os sentidos e a memória possível que o público possa acessar de sua infância.

A estrutura atual do espetáculo acontece em qualquer espaço cênico fechado. A iluminação é concebida no jogo de luz e sombra, contendo uma iluminação geral branca e seis lanternas que são manipuladas pelos atuadores e o técnico de som e luz. O figurino é simples e todo branco: para os atores-performers, bermudas e camisas de mangas curtas, para a atriz-performer, vestido branco.

Concebemos a sonoplastia do espetáculo através de colagem com fragmentos da obra fonográfica de Adélia Prado que gravou dois CDs recitando poemas de sua autoria, incluiu-se também fragmentos musicais da obra fonográfica de Cida Moreira. Essas duas vozes compõem a dramaturgia, tecendo junto com a ação física dos(as) artistas da cena a narratividade do espetáculo, ora elas são personas invisíveis, ora pano de fundo sonoplástico.

No presente, tentamos redimensionar junto ao público as amarrações dramatúrgicas e, como a obra versa sobre corpos afetivamente constrangidos, temos, como resolução desse estágio, que é preciso uma honestidade criativa, pois as cenas selecionadas para compor a fabulação só reverberam seu significado primário, motivo pelo qual ela existe, principalmente se tiver arraigada de sentido interior para cada participante na ação.

Durante as apresentações públicas, por abordarmos uma pesquisa guiada pela prática e, estarmos em contínuo processo, se faz necessário deglutirmos constantemente os fragmentos de poemas e músicas, buscando encontrar na corporeidade sentidos humanizantes e universais que nos liberem dos constrangimentos e possam, assim, compor a lógica interna da encenação. Desta feita, cada apresentação é particular, não só pelas acepções efêmeras que

ALVES, Mauro Cesar. Corpos constrangidos em potência de sentidos: rastros criativos do espetáculo cacos para um vitral - grupo oitão cênico - Cariri/CE. Revista da FUNDARTE, Montenegro, p.190211, ano 19, no 38, abril/junho de 2019.

Disponível em: http://.seer.fundarte.rs.gov.br/index.php/RevistadaFundarte/index> 28 de junho de 2019. 


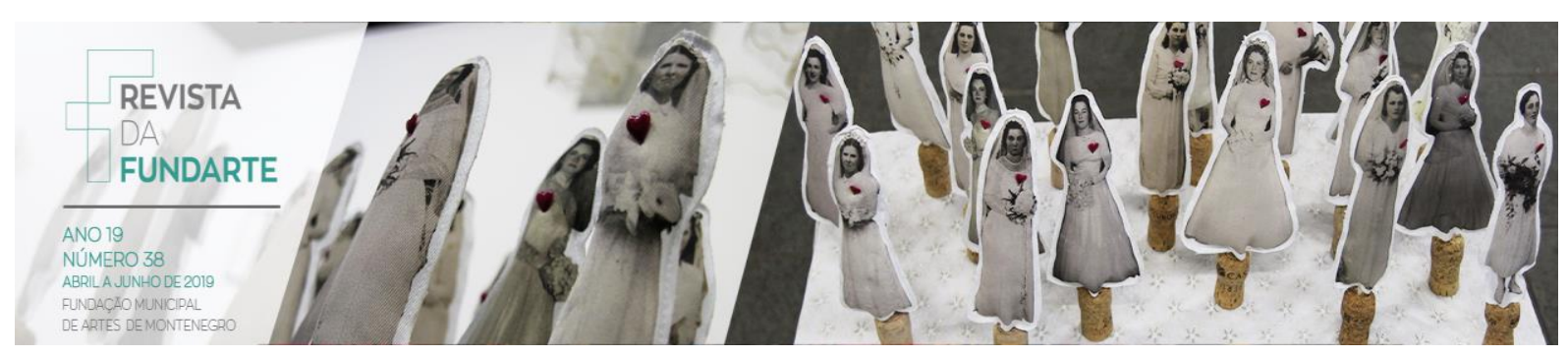

circundam a criação teatral, mas também pela própria dinâmica das escolhas metodológicas e dramatúrgica geradas no percurso de criação e pesquisa.

\section{In/Conclusões de um vitral}

A noção de 'corpo constrangido' no processo criativo do espetáculo Cacos para um vitral parte de vivências em que, memórias traumáticas, dolorosas, repulsivas e/ou ridículas dos(as) artistas da cena são presentificadas repercutindo em seus corpos, de modo a transformar experiência em poética. Do ponto de vista da psicologia moderna, segundo Gouveia (2006, p. 331 apud PARROTT, 1996), "o constrangimento é a mais social de todas as emoções e que requer um reconhecimento das convenções sociais, assim como uma representação das crenças e avaliações dos outros", o que inclui uma condição de reação psicológica ao comportamento de satisfazer o desejo de agir segundo as perspectivas e os interesses dos demais.

A imersão dessa experiência dos integrantes do Oitão no trajeto artístico escolhido problematiza a exposição de corpos na cena em situação de constrangimentos, questionando 0 assujeitamento sociocultural em que as subjetividades através dos julgamentos morais nos impuseram, com a finalidade de obedecermos aos ditames e regras estabelecidas e, agirmos conforme os interesses do poder dominante, de modo a capturar o corpo como mero reprodutor do capital, no entanto, "ao lado do poder, há sempre a potência. Ao lado da dominação, há sempre a insubordinação [...] E trata-se de cavar, de continuar a cavar, a partir do ponto mais baixo [...] pois tudo isso é vida e não morte". (PELBART al NEGRI, 2003, p. 27).

Nessa perspectiva, Cacos para um vitral trata-se não apenas de um espetáculo enquanto resultante de um projeto estático, mas sim das implicações que uma compreensão descolonizada de corpo, de cena, e do que o próprio espetáculo enquanto modus vivendi pode trazer para a pesquisa nas artes cênicas, em especial

ALVES, Mauro Cesar. Corpos constrangidos em potência de sentidos: rastros criativos do espetáculo cacos para um vitral - grupo oitão cênico - Cariri/CE. Revista da FUNDARTE, Montenegro, p.190211, ano 19, no 38, abril/junho de 2019.

Disponível em: http://.seer.fundarte.rs.gov.br/index.php/RevistadaFundarte/index> 28 de junho de 2019. 


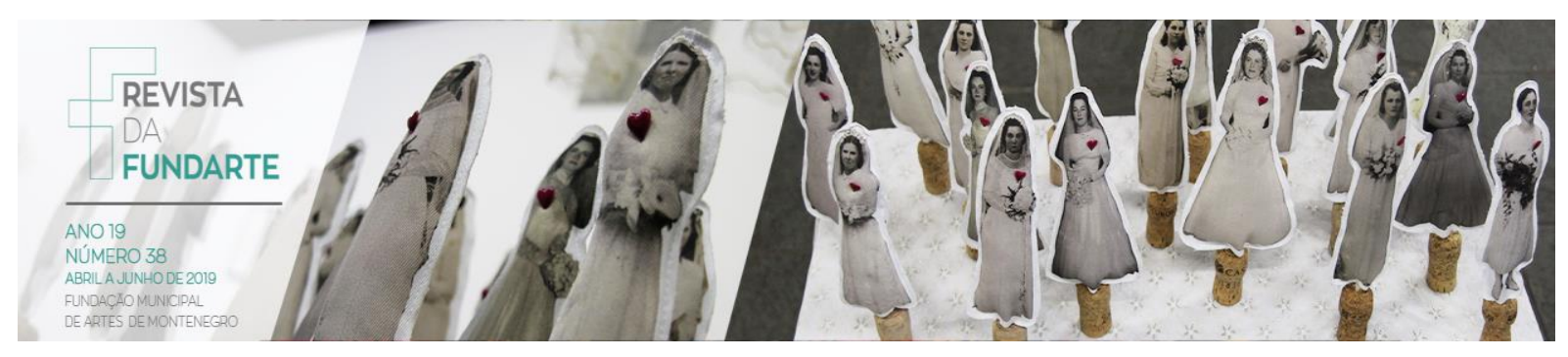

as que têm no corpo seu principal dispositivo, como propõe André Lepecki (2003, p. 5) ao se "pensar a dança enquanto crítica silenciosa dos corpos colonizados" com o intuito de ponderar o chão em que o bailarino pisa e tentar, a partir dessa observação, identificar os corpos que foram enterrados sem cuidados pela história.

Buscamos um processo de ressignificação do sentir, nos jogando cenicamente em um campo afetivo, até então, desconhecido por todos(as) nós. As saídas criativas se estabeleceram ao emergir novos conteúdos que nos guiavam a partir da observância que fazíamos das experimentações cênicas, revisitando nossos próprios afetos, produzindo, assim, conhecimento tácito e individual, compartilhado na criação coletiva.

Portanto, estando o espetáculo com uma estrutura apta para o compartilhamento com o público, não dispomos de nenhuma certeza, até o momento que o questionamento inicial foi respondido, pois o mesmo encontra-se em aberto, no entanto, todo procedimento gerou muito esforço e descobertas na tentativa de aplicarmos a arte como ferramenta de conhecimento e indicativo de um ethos. Um caminho metodológico possível por meio de uma poética de grupo comprometida com a pesquisa em continuidade no processo criativo.

A poetisa Adélia Prado aborda que a obra de arte como expressão de nossos afetos convida o público à experiência artística. A partir dessa premissa nos apropriamos do termo "educação dos afetos" utilizado pela autora e projetamos desenvolver uma metodologia que materialize esses dizeres por meio da prática cênica do Oitão. Esse intento busca mediar o processo de criação do espetáculo para os possíveis interessados nos índices da sua construção. Essa abordagem tem o intuito de compartilhar as vertentes do fazer cênico em perspectiva mais humana ao problematizar que o universo sensível que circunda os processos de criação e, muitas vezes, o menosprezamos, apresenta uma real importância na vida ética e política de uma obra artística.

ALVES, Mauro Cesar. Corpos constrangidos em potência de sentidos: rastros criativos do espetáculo cacos para um vitral - grupo oitão cênico - Cariri/CE. Revista da FUNDARTE, Montenegro, p.190211, ano 19, no 38, abril/junho de 2019.

Disponível em: http://.seer.fundarte.rs.gov.br/index.php/RevistadaFundarte/index> 28 de junho de 2019. 


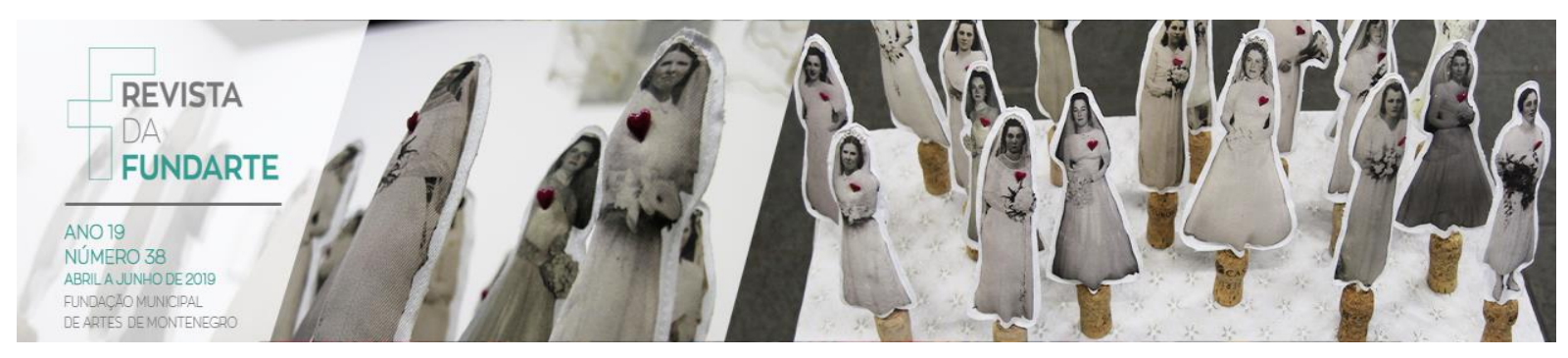

\section{Referências:}

DELEUZE, Gilles. Bergsonismo. Trad. Luiz B. L. Orlandi. São Paulo: 34, 1999. . Les cours de Gilles Deleuze: Deleuze/Spinoza. [on-line]. 1978, http://www.webdeleuze.com/php/texte.php?cle=194\&groupe=Spinoza\&langue=5

FÉRAL, Josette. Por uma poética da performatividade: o teatro performativo. Sala Preta, São Paulo, v.8, n.1, 2008.

FERNANDES, Silvia. Teatralidades contemporâneas. S. Paulo: Perspectiva, 2010.

FERREIRA, Aurélio Buarque de Holanda. Dicionário da língua portuguesa. 5. ed. Curitiba: Positivo, 2010. 2222 p.

GOUVEIA, Valdiney Veloso; SINGELIS, Theodore; GUERRA, Valeschka Martins; RIVERA, Giovani Amado; VASCONCELOS, Tatiana Cristina. O sentimento de constrangimento: evidências acerca do contágio emocional e do gênero. Estud. psicol. (Campinas); 23(4): 329-337, out.-dez. 2006.

HOUAISS, A. Villar, M. de S.; Franco, F. M. M. Dicionário Houaiss da língua portuguesa. Rio de Janeiro: Objetiva, 2009.

LEPECKI, André. O corpo colonizado. GESTO: Revista do Centro Coreográfico do Rio, vol. 3, n. 2. Rio de Janeiro: RioArte, p. 7-11, jul. 2003.

MEDEIROS, Mônica. Corpo, afeto e cognição na rítmica corporal de lone de Medeiros: entrelaçamento entre ensino de arte e ciências cognitivas. 2012. $324 \mathrm{f}$. Tese (Doutorado) - Escola de Belas Artes, Universidade Federal de Minas Gerais, Belo Horizonte. 2012.

MORENO, J. L. O Teatro da Espontaneidade. São Paulo: Summus, 1973. . Psicodrama. São Paulo: Editora Cultrix, 1975.

PAIS, Ana. Comoção: os ritmos afectivos do acontecimento teatral. 2014. 290 f. Tese (Doutorado) - Universidade de Lisboa, Lisboa. 2014

PELBART, Peter Pál. Vida capital: ensaios de biopolítica. São Paulo: lluminuras, 2003.

PRADO, Adélia. O poder humanizador da poesia. Trans. Bruno Costa Magalhães. Disponível em: http://expedicoesliterarias.blogspot.com.br/2012/03/o-poderhumanizador-d poesia.html

ALVES, Mauro Cesar. Corpos constrangidos em potência de sentidos: rastros criativos do espetáculo cacos para um vitral - grupo oitão cênico - Cariri/CE. Revista da FUNDARTE, Montenegro, p.190211, ano 19, no 38, abril/junho de 2019.

Disponível em: http://.seer.fundarte.rs.gov.br/index.php/RevistadaFundarte/index> 28 de junho de 2019. 


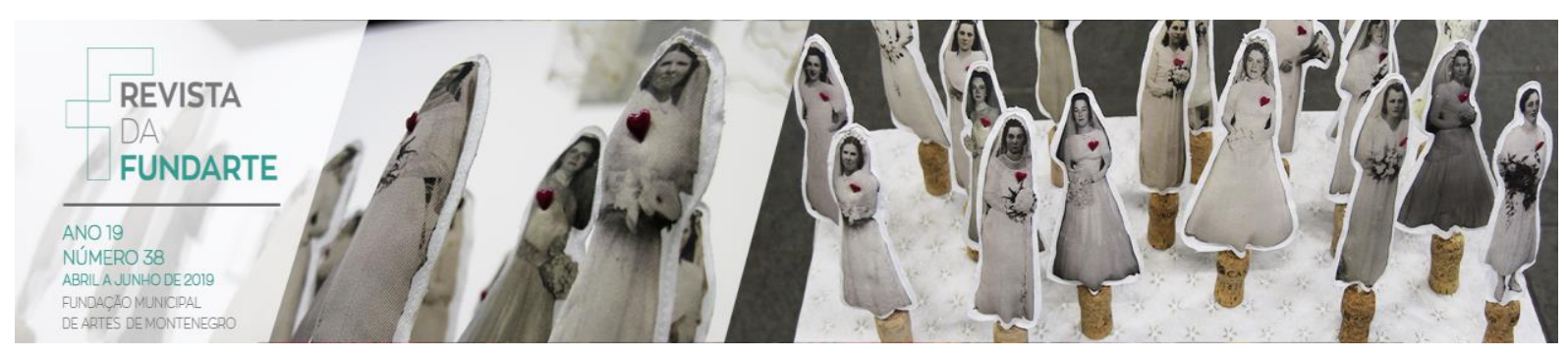

SALLES, Cecília Almeida. Gesto Inacabado: processo de criação artística - 2ªedição. São Paulo: FAPESP: Annablume, 2004.

Horizonte, 2008.

. Redes da criação: construção da obra de arte. São Paulo:

SPINOZA, Baruch. Ética. Trad. de Tomaz Tadeu. Belo Horizonte: Autêntica Editora, 2009.

ALVES, Mauro Cesar. Corpos constrangidos em potência de sentidos: rastros criativos do espetáculo cacos para um vitral - grupo oitão cênico - Cariri/CE. Revista da FUNDARTE, Montenegro, p.190211, ano 19, no 38, abril/junho de 2019.

Disponível em: http://.seer.fundarte.rs.gov.br/index.php/RevistadaFundarte/index> 28 de junho de 2019. 